Published in final edited form as:

Methods Enzymol. 2009 ; 453: 287-304. doi:10.1016/S0076-6879(08)04014-7.

\title{
AUTOPHAGY IN LUNG CANCER
}

\author{
Jerry J. Jaboin ${ }^{*}$, Misun Hwang ${ }^{*}$, and Bo Lu ${ }^{*}$ \\ "Department of Radiation Oncology, Vanderbilt Ingram Cancer Center, Vanderbilt University \\ School of Medicine, Nashville, Tennessee, USA
}

\begin{abstract}
Lung cancer is the leading cause of cancer-related deaths worldwide. The relatively poor cure rate in lung cancer patients has been associated with a resistance to chemotherapy and radiation that is at least in part related to defects in cellular apoptotic machinery. Exploitation of another form of cell death, autophagy, has the capacity to improve the therapeutic gain of current therapies. In an effort to develop novel treatment strategies to enhance the therapeutic ratio for lung cancer, we wish to better understand the role of autophagic cell death for the sensitization of lung cancer. This text reviews the most up to date protocols and techniques for the study of autophagic cell death in lung cancer models. Others may use these techniques as a framework for study within their experimental models.
\end{abstract}

\section{INTRODUCTION}

Lung cancer is the most prevalent cancer worldwide. Despite improvements in multimodality therapy, it continues to be the leading cause of cancer-related death in the United States, with an estimated 161,840 deaths in 2008 (Jemal et al., 2008). The majority of lung cancer patients present with advanced disease, and standard therapeutic regimens include radiation, platinum-based chemotherapy, and, rarely, surgery. Though there have been advances in radiation delivery, enhanced platinum pharmacological profiles, introduction of targeted biological agents and optimization of treatment schedules, there is still significant room for improvement in both the prognosis and side-effect profiles for this patient population (Rigas and Kelly, 2007).

A major barrier to curative therapy in lung cancer is the dysregulation of cell death signaling (Abend, 2003; Fesik, 2005; Melet et al., 2008; Moretti et al., 2007). Of the cellular death processes, apoptosis has been the best studied. Multiple investigators have demonstrated that deficits in apoptotic machinery can lead not only to abnormal proliferation but also to insensitivity to cytotoxic therapy. In fact, there have been efforts over the past decade to enhance apoptosis utilizing various activating antibodies, peptides and small molecules to restore the apoptotic machinery of tumor cells for the purpose of triggering cell death or rendering tumor cells more sensitive to chemotherapy and radiation (Fesik, 2005).

Autophagic (type II or macroautophagic) cell death was described as early as the 1970s, as a cell death mechanism that can occur independent of apoptosis (Clarke, 1990). It is an evolutionarily conserved process, which morphologically involves the formation of doublemembrane-bound autophagic vacuoles, called autophagosomes (Baehrecke, 2002; Reggiori et al., 2004a,b). These autophagosomes degrade and recycle proteins and cellular organelles by fusing with lysosomes to form autolysosomes (Levine and Klionsky, 2004). The role of autophagy in mammalian cell death is suggested by a study that implicates the autophagic genes, ATG7 and beclin 1 Shimizu et al., 2004; Yu, 2004). These studies not only demonstrate an antagonistic interplay between apoptosis and autophagic cell death but also suggest that they are nonexclusive events that can at times be observed in the same 
senescent cell (Gonzalez-Polo et al., 2005; Shimizu et al., 2004; Yu, 2004). The role of autophagy in cell death is still controversial, however, and a recent study finds that $A T G 7$ and beclin 1 act in a protective manner in the same system (Wu et al., 2008).

Autophagy has multiple roles in the promotion of carcinogenesis. It ensures survival in nutrient-poor conditions through lysosomal recycling of intracellular nutrients, which is proposed to allow time for the development of adaptive changes in gene expression and metabolic activity (Ogier-Denis and Codogno, 2003). Additionally, it may promote evasion of chemotherapy and radiation-induced apoptosis through removal of damaged organelles (Boya et al., 2005; Lum, 2005; Ogier-Denis and Codogno, 2003; Paglin et al., 2001). Although the autophagic response to starvation is less pronounced in cancer cells, it is still up-regulated in many tumor types suggesting it is an important survival mechanism (Gozuacik and Kimchi, 2004; Ogier-Denis and Codogno, 2003).

Suppression of carcinogenesis has also been proposed to be an important feature of autophagy. Cancer cells that are unable to undergo apoptosis secondary to genetic mutations are still susceptible to autophagic cell death (Paglin et al., 2001). Additionally, some cancer cells are dependent on a blockade of autophagy for maintenance of their malignant phenotype (Liang et al., 1999). This hypothesis was tested in several experimental models of hepatic carcinogenesis, where preneoplastic nodules and frank hepatocellular carcinomas demonstrate decreased autophagic capacity as compared to normal liver cells (Canuto et al., 1993; Schwartz et al., 1993; Schwarze and Seglen, 1985). It is proposed that this decreased autophagic activity associated with malignant cells may be related to the prevention of excessive protein loss upon starvation of tumor cells (Canuto et al., 1993; Schwarze and Seglen, 1985).

Three are a number of cancer therapies that currently induce autophagy (Table 14.1). One of the most notable of these is temozolomide, which is a DNA alkylator that induces autophagy in malignant glioma cells (Kanzawa et al., 2004). This is the first chemotherapeutic agent that has demonstrated efficacy in this difficult population. In addition to temozolomide, there are multiple therapies that are known to induce autophagy. These include the class of histone deacetylase inhibitors (Shao et al., 2004), arsenic trioxide (Kanzawa et al., 2003, 2005), tamoxifen (Bursch et al., 1996, 2000), rapamycin (Takeuchi et al., 2005), and irradiation (Ito et al., 2005; Paglin et al., 2001; Yao et al., 2003). These drugs may actually cause autophagic cell death. For example, 3-methyladenine (3-MA) is an inhibitor of autophagosome formation and prevents tamoxifen-induced cell death in breast cancer cells (Paglin et al., 2001). However induction of autophagy does not necessarily signify a causal therapeutic benefit. For example, 3-MA treatment results in radiosensitization with increased cell death observed in irradiated malignant glioma cells (Ito et al., 2005). In the case of irradiation, induction of autophagy may represent a survival mechanism, or the balance of cellular decisions is tipped toward apoptotic death.

The rapid evolution in the study of autophagy has prompted a recent publication to establish guidelines to more clearly establish a basic foundation for the understanding of autophagic processes.(Klionsky et al., 2008) The authors outline the current tools that at a minimum should be used by investigators to determine whether full autophagy (autophagic flux) has occurred, rather than accumulation of markers of autophagy, such as the autophagosome. Our text will outline these protocols with a special emphasis on the study of lung cancer models. 


\section{METHODS}

\subsection{Cell culture}

We utilize multiple cell lines in the study of cell death in lung cancer tumors. Primary mouse embryonic fibroblasts (MEFs) are a useful tool in the study of cell death mechanisms within various genetic backgrounds. We use MEFs with deficiencies in various key apoptotic proteins (e.g., caspases, Bcl-2 family members) to characterize cell death in response to irradiation with and without other cytotoxic agents (Kim et al., 2008a,b). To complement these studies, we also evaluated well-characterized human lung cancer cell lines (e.g., H460) in vitro and in vivo. As neoangiogenesis also plays an important part in tumor control, we perform experiments with human umbilical vein endothelial cells (HUVECs) as a surrogate for tumor blood vessel response (Albert et al., 2006; Cao et al., 2005; Kim et al., 2008a,b).

1. MEFs are derived from wild-type (WT), caspase- $3^{-1-} / 7^{-1-}$ double knockout (DKO) mice and Bax-Bak DKO mice. They are then immortalized by transfection with a plasmid containing SV40-T-antigen.

a. The MEFs are cultured in Dulbecco's Modified Eagle's Medium (DMEM) supplemented with $10 \%$ fetal bovine serum (FBS), $1 \%$ penicillinstreptomycin (Invitrogen, Cat. No. 10313-039) and $0.5 \mu \mathrm{mol} / \mathrm{L} \mathrm{2-}$ mercaptoethanol at $37^{\circ} \mathrm{C}$.

2. NCI-H460 (H460) lung cancer cells are obtained from ATCC (Cat. No. HTB-177).

a. The H460 cells are cultured in RPMI 1640 (Invitrogen, Cat. No. 11875-119) supplemented with $10 \%$ fetal bovine serum and $1 \%$ penicillinstreptomycin at $37{ }^{\circ} \mathrm{C}$ and humidified $5 \% \mathrm{CO}_{2}$.

3. Human Umbilical Vein Endothelial Cells (HUVECs) are obtained from Clonetics (now Lonza, Cat. No. CC-2519).

a. HUVECs are maintained in EBM-2 medium (Clonetics (now Lonza), Cat. No. CC-3156) supplemented with EGM-2 MV (Bio-whittaker (now Lonza), Cat. No. CC-4147) single aliquots at $37^{\circ} \mathrm{C}$.

\subsection{Drugs in autophagy analysis}

We utilize various drugs in our studies and these agents serve various purposes (Table 14.1). The lysosomal protease inhibitors help verify the presence of autophagic flux. By blocking lysosomal degradation, we can evaluate the time-dependent accumulation of autophagosomes and LC3-II (Klionsky et al., 2008). This allows for better differentiation of the presence of autophagosome accumulation versus changes in the rates of autophagic degradation (Klionsky et al., 2008).

Inhibitors of autophagy (e.g., 3-methyladenine) are necessary in the validation of autophagy. They are most often used to determine a change in autophagosome production, as determined by GFP-LC3 puncta formation in response to therapy (Shintani, 2004). They can also be used to monitor and estimate the turnover rates of autophagic organelles (e.g., autophagosomes, autolysosomes) (Kirkegaard et al., 2004; Shintani, 2004). There is also a complex interplay between apoptosis and autophagy (Jaboin et al., 2007). We use inhibitors of apoptosis (e.g., caspase inhibitors) to better study this relationship.

The number of inducers of autophagy has been growing steadily over the past decade. These agents vary in their specificity and abilities to induce cell death, but some may prove extremely useful for the improvement of therapeutic ratio in a host of tumors. Listed in 
Table 14.1 are a few of the better characterized agents that either stimulate or inhibit autophagy (Lefranc et al., 2007).

\subsection{Clonogenic assay}

The clonogenic assay is an in vitro cell survival assay that has been the standard for evaluating reproductive cell death following irradiation for many years (Franken et al., 2006). It has the advantage of analysis of cell death without significant confounding factors of changes in cellular proliferation or metabolic changes. This tool is useful in the study of various cellular models, and multiple cytotoxic agents.

1. H460 cells and MEFs are treated with DMSO or drug (e.g. M867) at varying concentrations (1.4, 5, and $10 \mathrm{n} M$ in H460 cells; 5 and $10 \mathrm{n} M$ in MEFs) for a period $24 \mathrm{~h}$ at $37^{\circ} \mathrm{C}$ in $60-\mathrm{mm}$ tissue culture dishes.

2. Cells are subsequently treated with siRNAs against empty vector, caspase-3, caspase-7, beclin 1, and/or ATG5.

3. Cells are then irradiated with $0-6 \mathrm{~Gy}$ at a dose rate of $1.8 \mathrm{~Gy} / \mathrm{min}$ using a ${ }^{137} \mathrm{Cs}$ irradiator (J.L. Shepherd and Associates, Glendale, CA).

4. After irradiation, cells are incubated at $37^{\circ} \mathrm{C}$ to allow for at least 6 cell divisions, which typically is a period of 6-14 days.

5. The medium is removed, and cells are then fixed for 15 min with 3:1 methanol: acetic acid and stained for 15 min with $0.5 \%$ crystal violet (Sigma-Aldrich, Cat. No. C0775) in methanol.

6. Following staining, colonies are counted. A colony is defined as containing a minimum of 50 viable cells.

7. Surviving fraction is calculated as (mean colony counts)/(cells inoculated) $\times$ (plating efficiency (PE)), where PE is defined as (mean colony counts)/(cells inoculated for nonirradiated controls).

8. Dose enhancement ratio (DER) is calculated as the dose (Gy) for radiation alone divided by the dose (Gy) for radiation plus drug (normalized for drug toxicity) necessary for a surviving fraction of 0.25 . Experiments are conducted in triplicate and mean, standard deviation, and $\mathrm{P}$ values are calculated.

\subsection{Endothelial cell morphogenesis assay: tubule formation}

Angiogenesis is an important facet of cancer therapy, as it is critical in maintaining nourishment after tumors reach a critical size (Folkman, 2007). As such, in vitro studies of novel drugs and combination therapies would not be complete without an analysis of tumor endothelial cells. Most of our studies have been performed utilizing human umbilical vein endothelial cells, as a surrogate for tumor endothelial cells (Albert et al., 2007; Kim et al., 2008a).

1. HUVECs are grown to $70 \%$ confluency, and treated with DMSO, Z-DEVD (50 $\mu M$ for $24 \mathrm{~h}$ ), RAD001 (10 $\mathrm{n} M$ for $2 \mathrm{~h}$ ) or combined Z-DEVD with RAD001 (at the same doses for a period of $24 \mathrm{~h}$ ), and then cells are treated with $5 \mathrm{~Gy}$.

2. The media is removed from the culture dish and washed once with PBS. The PBS is aspirated, and $1 \mathrm{ml}$ of trypsin-EDTA is added to the plate. The plate is rocked to ensure that the entire surface is covered. Incubate the dish at room temperature for 1-3 min, and observe under a microscope. When the cells are completely round, gently dislodge the cells from the surface of the dish by rapping. 
3. They are seeded at 48,000 cells per well on 24 -well plates coated with $300 \mu \mathrm{l}$ of Matrigel (BD Biosciences, Cat. No. 354234).

4. The cells undergo differentiation into capillary-like tube structures, and are periodically observed by microscopy.

5. Twenty-four h later, cells are stained with hematoxylin and eosin and photographs are taken via microscopy.

6. The average number of tubes is calculated from examination of three separate microscope fields (100X) and representative photographs are taken.

\subsection{Analysis of autophagosomes (Immunofluorescence Microscopy)}

Detection of fluorescence-tagged GFP is a useful tool for the microscopy detection of autophagosome production. LC3 is tagged with GFP at the amino terminus. The cells are subsequently transiently transfected to overexpress the GFP-LC3 proteins, and treated in various cellular conditions. At various time points, the cells are analyzed by confocal microscopy with images recorded for analysis of punctate GFP-LC3 as an indication of autophagosome production.

There are limitations to this strategy. A stable transfection may result in fewer artifacts, and decreased background over transient transfection (Klionsky et al., 2008). Analysis would also be easier, because nearly every cell would express the GFP-LC3. Generally we prefer the transient transfection method, as the effect of LC3 overexpression is detected shortly after transfection, which theoretically reduces alterations of the cellular machinery over the time it would take to generate stable transfectants.

1. H460 cell and MEFs are seeded at a density of $2 \times 10^{5}$ cells into 6-well tissue culture plates.

2. After $16 \mathrm{~h}$, the cells are transfected with $2.5 \mu \mathrm{g}$ of GFP-LC 3 expression plasmid using the Lipofectamine 2000 reagent (Invitrogen Life Technologies, Cat. No. 12566-014) per the manufacturer's protocols.

3. Twenty-four $\mathrm{h}$ later, the cells are treated with $5 \mathrm{~Gy}$ of radiation, with or without drug.

4. After 24 and $48 \mathrm{~h}$ time points, the fluorescence of GFP-LC3 is observed using confocal microscopy.

\subsection{Immunoblotting}

Western immunoblotting has been useful for the evaluation of autophagic proteins in our models. In mammalian systems, determinations of the total levels of LC3 is not sufficient, as it does not account for the variations in conversion and degradation of LC3-I and LC3-II (Klionsky et al., 2008). Thus, Western analysis of LC3-I and LC3-II, and determination of a LC3-II/LC3-I ratio has been considered a good marker for autophagy.

There are limitations to this approach. Changes in LC3-I and LC3-II levels vary with cell type and conditions, which can present significant challenges for heterogeneous populations (Mizushima et al., 2004). Also there are reported variations in the sensitivity of various antibodies to LC3-I with less lability associated with LC3-II (Klionsky et al., 2008). That combined with the fact that LC3-II is degraded by autophagy can confound assessments. Finally, LC3-II and the LC3-II/LC3-I ratio can represent autophagosome accumulation at a given point in time. It is better to also assess LC3-II in the presence and absence of lysosomal protease inhibitors to determine the amount of LC3-II delivered to lysosomes, which is a better determination of autophagic flux (Mizushima and Yoshimori, 2007). 
1. H460 cells $\left(0.5 \times 10^{6}\right)$ are treated with varying doses of radiation and drugs.

2. They are subsequently collected at multiple time points, and washed with ice-cold PBS twice before the addition of lysis buffer (20 mM Tris-HCl, pH 7.4, $150 \mathrm{~m} M$ $\mathrm{NaCl}, 20 \mathrm{~m} M$ EDTA, $1 \% \mathrm{NP} 40,50 \mathrm{~m} M \mathrm{NaF}, 1 \mathrm{mM} \mathrm{Na}_{3} \mathrm{Vo}_{4}, 1 \mathrm{~m} M \mathrm{NaMO}_{4}$ and protease cocktail inhibitor (Sigma-Aldrich, Cat. No. P8340)).

3. Protein concentration is quantified using the Bio-Rad protein assay kit (Bio-Rad, Cat. No. 500-0001).

4. An equal amount of $2 X$ SDS-polyacrylamide gel electrophoresis sample loading buffer is added to each sample, and the samples are heated at $100{ }^{\circ} \mathrm{C}$ for $5 \mathrm{~min}$.

5. Equal amounts of protein are loaded into each well, and resolved on a $12.5 \%$ SDSPAGE gel.

6. The blots are transferred to a polyvinylidene difluoride (PVDF) membrane at 300 $\mathrm{mA}$ for $3 \mathrm{~h}$ at $4{ }^{\circ} \mathrm{C}$.

7. The PVDF membranes are blocked using $5 \%$ nonfat dry milk in TBS-T (Trisbuffered saline (TBS) and $0.1 \%$ Tween-20 with 5\% nonfat dry milk) for $1 \mathrm{~h}$ at room temperature.

8. The blots are then incubated with various primary antibodies in TBS with 5\% nonfat milk for $1 \mathrm{~h}$ at room temperature or overnight at $4{ }^{\circ} \mathrm{C}$.

a. Rabbit anti-LC3 polyclonal antibody: Medical \& Biological Laboratories ITL, Cat. No. PD012
i. LC3-I: $16 \mathrm{kDa}$
ii. LC3-II: $18 \mathrm{kDa}$

b. Rabbit anti-caspase-3 polyclonal antibody: Cell Signaling, Cat. No. 9662

i. Full length caspase-3: $35 \mathrm{kDa}$

ii. Cleaved caspase-3: $17 \mathrm{kDa}$

c. Rabbit anti-caspase-7 polyclonal antibody: Cell Signaling, Cat. No. 9492

i. Full length caspase-7: $35 \mathrm{kDa}$

ii. Cleaved caspase-7: $20 \mathrm{kDa}$

d. Rabbit anti-Akt polyclonal antibody: Cell Signaling, Cat. No. 4685

i. Akt: $60 \mathrm{kDa}$

e. Rabbit anti-phospho-Akt (Ser-473) monoclonal antibody: Cell Signaling, Cat. No. 4058

i. Phospho-Akt: $60 \mathrm{kDa}$

f. Rabbit anti-S6 ribosomal protein monoclonal antibody: Cell Signaling, Cat. No. 2217

i. S6 ribosomal protein: $32 \mathrm{kDa}$

g. Rabbit anti-phospho-S6 ribosomal protein (Ser-240/244) monoclonal antibody: Cell Signaling, Cat. No. 4838

i. Phospho-S6 ribosomal protein: $32 \mathrm{kDa}$ 
h. Rabbit anti-Actin polyclonal antibody: Santa Cruz Biotech, Cat. No. sc-10731

i. Actin: $45 \mathrm{kDa}$

9. The membranes are washed with TBS-T 3 times for $10 \mathrm{~min}$.

10. Then, the membranes are incubated with the appropriate secondary antibodies conjugated to horseradish peroxidase for $45 \mathrm{~min}$ at room temperature.

11. Immunoblots are developed by using the chemiluminescence detection system (PerkinElmer) according to the manufacturer's protocol and autoradiography.

\subsection{Quantification of autophagic flux}

To distinguish between autophagic induction and autophagic flux, we assay for the levels of LC3-II by Western analysis following treatment with either 3-MA or lysosomal protease inhibitors.

1. H460 cells are seeded in 6 -well tissue culture plates at a density of $2 \times 10^{5}$ cells.

2. Sixteen $\mathrm{h}$ later, the cells are treated with Z-DEVD $(50 \mu M$ for $24 \mathrm{~h})$.

3. Then $23 \mathrm{~h}$ later, if indicated, the cells are treated with RAD001 ( $10 \mathrm{n} M$ for $1 \mathrm{~h})$.

4. One $\mathrm{h}$ later, the cells are irradiated at $5 \mathrm{~Gy}$, and then treated with either $200 \mu M 3$ MA or a combination of pepstatin A $(10 \mu \mathrm{g} / \mathrm{ml})$ and E64d $(10 \mu \mathrm{g} / \mathrm{ml})$ for a period of $2 \mathrm{~h}$.

5. Cells are then collected at 2 time points ( 24 and $48 \mathrm{~h}$ ), and washed with ice-cold PBS twice before lysis and protein concentration determination (as described previously).

6. The lysate is prepared as described previously, and then probed with anti-LC3 antibody in milk for a period of $1 \mathrm{~h}$.

7. The blots are washed 3 times with TBS-T for $10 \mathrm{~min}$.

8. Then the blots are reprobed with antiactin antibody for standardization of LC3-II levels to actin.

In addition, the LC3-II/LC3-I ratio can be determined.

\subsection{Analysis of apoptosis}

There are multiple methods to detect and quantify apoptosis which include, but are not limited to, end labeling of DNA, detection of phosphatidylserine changes, DNA laddering, and Western analysis of apoptosis signaling proteins. In our studies, we find that utilizing flow cytometric analysis of phosphatidylserine changes provides reliable and reproducible quantitative analysis of early apoptosis change in response to our various cytotoxic conditions.

1. H460 cells $\left(2.5 \times 10^{5}\right)$ are plated into $10-\mathrm{mm}$ dishes for each data point.

2. After $24 \mathrm{~h}$ of incubation at $37^{\circ} \mathrm{C}$, the cells are treated with drug and immediately irradiated with $3,5,10$, or $20 \mathrm{~Gy}$.

3. Twenty-four h later, the cells are treated with $1 \mathrm{ml}$ of the cell detachment medium Accutase (Millipore, Cat. No. SCR005) for $4 \mathrm{~min}$ and then cell counts are recorded for each sample. 
4. Cells are centrifuged at $2000 \mathrm{rpm}$ at $4{ }^{\circ} \mathrm{C}$ for $15 \mathrm{~min}$, and resuspended in $1 \mathrm{X}$ Annexin V Binding Buffer (BD Biosciences, Cat. No. 51-66121E) at a concentration of $1 \times 10^{6}$ cells $/ \mathrm{ml}$.

5. One hundred microliters of each solution $\left(1 \times 10^{5}\right.$ cells $)$ is transferred into $12 \times 75$ $\mathrm{mm}$ ml FACS tubes (BD Biosciences, Cat. No. 340265) to which is added $1.2 \mu \mathrm{l}$ of Annexin V-FITC (BD Biosciences, Cat. No. 556570) and $1.2 \mu \mathrm{l}$ of propidium iodide.

6. After $30 \mathrm{~min}$ incubation at room temperature in the dark, $400 \mu \mathrm{l}$ of $1 \mathrm{x}$ binding buffer is added to each tube.

7. The rate of apoptosis (as determined by external membrane translocation of phosphatidylserine) is measured using the Annexin V-Fluorescein Isothiocyanate Apoptosis Detection Kit II (BD Biosciences, Cat. No. 556570) with flow cytometry per the manufacturer's protocols.

\subsection{Gene knockdown utilizing siRNA transfection}

Genetic manipulation utilizing siRNA can be a relatively simple way to associate a given agent to an effect. The limitations of these experiments are similar to those discussed with transient versus stable transfections of other proteins. However in the study of autophagy, where causal relationships are difficult to establish, determining the mediators of a given effect is particularly important.

1. We use siRNAs against various proteins:

a. siRNA mouse caspase-3; Santa Cruz Biotechnology, Cat. No. sc-29927

b. siRNA mouse caspase-7; Santa Cruz Biotechnology, Cat. No. sc-29928

c. siRNA mouse Beclin 1; Santa Cruz Biotechnology, Cat. No. sc-29798

d. siRNA mouse ATG5

e. 5'-AACUUGCUUUACUCUCUCAUCAUU-39 (Sense)

f. 3'-UUUUGAACGAAAUGAGAGAUAGU-59 (Antisense)

g. Control siRNA; Santa Cruz Biotechnology, Cat. No. sc-37007

2. Cells are transfected with $25 \mathrm{n} M$ of siRNAs using Lipofectamine 2000 (Invitrogen Life Technologies, Cat. No. 12566-014).

3. The transfected cells are used for experiments $24 \mathrm{~h}$ later.

\subsection{Human lung cancer xenograft}

1. Human H460 lung cancer cells are used in a xenograft model in female athymic nude mice (nu/nu), 5-6 weeks old.

2. A suspension of $1 \times 10^{6}$ cells in $50 \mu \mathrm{L}$ volume is injected subcutaneously into the left posterior flank of mice using a 271/2-gauge needle.

3. Tumors are grown for $6-8$ days until the average tumor volume reaches $0.25 \mathrm{~cm}^{3}$.

4. Treatment groups consist of vehicle control (DMSO), drug, vehicle plus radiation, and drug plus radiation. Each treatment group contains 5 mice.

5. DMSO or drug is given daily by intraperitoneal (i.p.) injection at doses of $2 \mathrm{mg} / \mathrm{kg}$ for 7 consecutive days. 
6. In the case of combination treatment, drug or vehicle is given for 2 days prior to the first dose of irradiation.

7. Mice in radiation groups are irradiated $1 \mathrm{~h}$ after drug or vehicle treatment with daily 2 Gy fractions given over 5 consecutive days.

8. Tumors on the flanks of the mice are irradiated using an X-ray irradiator (Therapax, AGFA NDT).

9. The non-tumor-bearing parts of the mice are shielded by lead blocks.

10. Tumors are measured $2-3$ times weekly in 3 perpendicular dimensions using a Vernier caliper and the volume is calculated using the modified ellipse volume formula $($ volume $=($ height $\times$ width $\times$ depth $) / 2)$.

11. Growth delay is calculated for treatment groups relative to control tumors.

\subsection{Immunohistochemistry}

1. Mice are implanted with $\mathrm{H} 460$ cells and treated as described previously in the tumor volume studies.

2. After 7 days of daily treatments, the mice are sacrificed and tumors are paraffin fixed.

3. Slides from each treatment group are then stained for von Willebrand factor (vWF) using anti-vWF polyclonal antibody (Millipore, Cat No. AB7356).

4. Blood vessels are quantified by randomly selecting $400 \mathrm{X}$ fields and counting the number of blood vessels per field.

5. This is done in triplicate and the average of the three counts is calculated. Ki67 and terminal deoxynucleotidyl transferase(TdT)-mediated dUTP nick end labeling (TUNEL) staining are performed in the Vanderbilt University pathology core laboratory according to the following protocols.

\subsubsection{Protocol: TUNEL staining}

\subsubsection{Solutions}

\begin{tabular}{lr}
\hline TdT Buffer Stock Solution: & \\
Tris-HCl (MW: 157.6) & $1.97 \mathrm{~g}$ \\
Sodium cacodylate, trihydrate (MW: 214.0) & $21.4 \mathrm{~g}$ \\
Bovine serum albumin (BSA) & $0.125 \mathrm{~g}$ \\
Distilled water & $100 \mathrm{ml}$ \\
Adjust pH to 6.6, and store aliquots at $-20{ }^{\circ} \mathrm{C}$. & \\
Cobalt Chloride Stock Solution: & \\
Cobalt chloride, hexahydrate (MW: 237.9) & $0.6 \mathrm{~g}$ \\
Distilled water & $100 \mathrm{ml}$ \\
Mix to dissolve, and store aliquots at $-20{ }^{\circ} \mathrm{C}$. & \\
TdT Reaction Buffer: & \\
TdT buffer stock solution & $40 \mu 1$ \\
Cobalt chloride stock solution & $8 \mu 1$ \\
Distilled water & $160 \mu 1$ \\
Mix well. Store at $-20{ }^{\circ} \mathrm{C}$. &
\end{tabular}




\begin{tabular}{ll} 
TdT Storage Buffer: & \\
Potassium phosphate $\left(\mathrm{K}_{2} \mathrm{HPO}_{4} ; \mathrm{MW}: 174.18\right)$ & $1.05 \mathrm{~g}$ \\
$\mathrm{KCl}(\mathrm{FW}: 74.55)$ & $1.12 \mathrm{~g}$ \\
Distilled water & $50 \mathrm{ml}$ \\
\hline
\end{tabular}

Stir to dissolve and adjust $\mathrm{pH}$ to $7.2 \mathrm{using}$ concentrated $\mathrm{HCl}$. Add $50 \mathrm{ml}$ of glycerin (100\% glycerol), $0.5 \mathrm{ml}$ of Triton X-100, and $8 \mu \mathrm{l}$ of 2-mercaptoethanol (99\% solution. FW: 78.13). Store at $-20^{\circ} \mathrm{C}$.

\subsubsection{Reagents}

\begin{tabular}{|c|c|}
\hline \multicolumn{2}{|l|}{ PBS: } \\
\hline Sodium phosphate, dibasic $\left(\mathrm{Na}_{2} \mathrm{HPO}_{4}\right)$ & $1.44 \mathrm{~g}$ \\
\hline Sodium chloride & $8 \mathrm{~g}$ \\
\hline Potassium phosphate $\left(\mathrm{KH}_{2} \mathrm{PO}_{4}\right)$ & $0.24 \mathrm{~g}$ \\
\hline Potassium chloride & $0.2 \mathrm{~g}$ \\
\hline Distilled water & $800 \mathrm{ml}$ \\
\hline \multirow{2}{*}{\multicolumn{2}{|c|}{$\begin{array}{l}\text { Adjust } \mathrm{pH} \text { to } 7.4 \text {, and adjust to a final volume of } 1 \text { liter with additional distilled water. } \\
\text { PBS-T (PBS/Tween Solution): }\end{array}$}} \\
\hline & \\
\hline \multicolumn{2}{|l|}{$0.1 \%$ volume of Tween 20 prepared in PBS } \\
\hline \multicolumn{2}{|l|}{ Triton X-100 (octylphenolpoly(ethyleneglycolether): } \\
\hline \multicolumn{2}{|l|}{ Roche Diagnostics, Cat. No. 11332481001.} \\
\hline \multicolumn{2}{|l|}{ Enzyme Reagent: } \\
\hline TdT (Roche Diag., Cat. No. 03333574001) & $4 \mu 1$ \\
\hline TdT storage buffer & $100 \mu 1$ \\
\hline \multicolumn{2}{|l|}{ Mix well and store at $-20^{\circ} \mathrm{C}$. } \\
\hline \multicolumn{2}{|l|}{ Label Reagent: } \\
\hline Biotin-16-dUTP (Roche Diag., Cat. No. 11093070910) & $4 \mu 1$ \\
\hline TdT reaction buffer & $1 \mathrm{ml}$ \\
\hline \multicolumn{2}{|l|}{ Mix well and store at $-20^{\circ} \mathrm{C}$. } \\
\hline \multicolumn{2}{|l|}{ TdT Reaction Mixture: } \\
\hline Enzyme reagent & $100 \mu 1$ \\
\hline Label reagent & $900 \mu 1$ \\
\hline \multicolumn{2}{|c|}{ Mix just before use. Use the remaining $100 \mu 1$ of label solution as a negative control. } \\
\hline \multicolumn{2}{|l|}{ Stop Wash Buffer: } \\
\hline $\mathrm{NaCl}$ (MW: 58.44) & $1.75 \mathrm{~g}$ \\
\hline Sodium citrate, trihydrate (MW: 294.11) & $0.88 \mathrm{~g}$ \\
\hline Distilled water & $100 \mu 1$ \\
\hline Mix to dissolve and store at room temperature. & \\
\hline
\end{tabular}

\subsubsection{Protocol}

1. Deparaffinize sections in 2 changes of xylene for 5 min each in labeled $2.0 \mathrm{ml}$ microcentrifuge tubes 
2. Hydrate with 2 changes of $100 \%$ ethanol for 3 min each, followed by $95 \%$ ethanol for $1 \mathrm{~min}$.

3. Rinse in distilled water.

4. Add $800 \mu \mathrm{l}$ of lysis buffer, and add $9 \mu \mathrm{l}$ of proteinase $\mathrm{K}(20 \mathrm{mg} / \mathrm{ml}$; Promega, Cat. No. V302B).

5. Vortex samples for $15 \mathrm{~s}$, and incubate at $55^{\circ} \mathrm{C}$ until tissue is completely lysed (may need to be overnight). Vortex samples occasionally.

6. Add $180 \mu \mathrm{L}$ of $5 \mathrm{M} \mathrm{NaCl}$ and vortex well. The solution will become frothy.

7. Spin tubes at $13,000 \mathrm{rpm}$ for $5 \mathrm{~min}$, and the salted out debris will pellet.

8. Transfer the supernatant fractions to cryotubes (screw cap).

9. Add $420 \mu \mathrm{L}$ of ice-cold isopropanol (2-propanol) to the supernatant fractions.

10. Mix slowly by inversion $5-10$ times. CAUTION: Do not vortex.

11. DNA fibers may be seen at this time.

12. Centrifuge the tube at $13,000 \mathrm{rpm}$ for $10 \mathrm{~min}$.

13. The DNA pellet should be visible

14. Pour out the supernatant to discard.

15. Add $400 \mu \mathrm{L}$ of $70 \%$ ethanol to wash the DNA pellet.

16. Wash for 20 min on a cell rotator at room temp.

17. Centrifuge the tubes at $13,000 \mathrm{rpm}$ for $5 \mathrm{~min}$ and pour out the ethanol carefully! Note that the pellet may be loose. If the pellet is loose, pipette the ethanol out, being careful to not disturb the pellet.

18. Dry the DNA pellet in a speed vac on high for $10 \mathrm{~min}$.

19. Resuspend the pellet in distilled $\mathrm{H}_{2} \mathrm{O}$.

a. If a small pellet add approximately $50 \mu \mathrm{L}$

b. If a large pellet add approximately $100 \mu \mathrm{L}$

20. Let the tubes stand at room temp overnight.

21. Perform 2 washes of 2 min each with PBS-T.

22. Incubate the sections in TdT Reaction Buffer for $10 \mathrm{~min}$.

23. Incubate the sections in TdT Reaction Mixture for $1-2 \mathrm{~h}$ at $37{ }^{\circ} \mathrm{C}$ in a humidified chamber.

24. Rinse the sections in stop wash buffer for $10 \mathrm{~min}$.

25. Perform 3 washes of 2 min each with PBS-T.

26. Counterstain with propidium iodide or DAPI for $20 \mathrm{~min}$.

27. Rinse in PBS for 5 min.

28. Mount the sections with antifading mounting medium.

The number of positive cells per field are scored and graphed by averaging 3 repeated assessments. 


\section{CONCLUSION}

Techniques for the analysis of autophagy have been rapidly evolving over the past decade. As a result, there has been a concerted effort by the leaders in this field to maintain strict guidelines regarding the interpretation and appropriate methods for analysis of autophagy (Klionsky et al., 2008). Though there have been relatively few studies into autophagy and its role in lung cancer, we hope that this chapter will serve as the basis for further investigations. As these techniques continue to evolve, it will be important to continue investigating this process to develop optimal therapeutic combinations for the improvement of therapeutic ratio in lung cancer.

\section{REFERENCES}

Abend M. Reasons to reconsider the significance of apoptosis for cancer therapy. Int. J. Radiat. Biol. 2003; 79:927-941. [PubMed: 14713571]

Albert JM, Cao C, Kim KW, Willey CD, Geng L, Xiao D, Wang H, Sandler A, Johnson DH, Colevas $\mathrm{AD}$, Low J, Rothenberg ML, et al. Inhibition of poly(ADP-ribose) polymerase enhances cell death and improves tumor growth delay in irradiated lung cancer models. Clin. Cancer Res. 2007; 13:3033-3042. [PubMed: 17505006]

Albert JM, Kim KW, Cao C, Lu B. Targeting the Akt/mammalian target of rapamycin pathway for radiosensitization of breast cancer. Mol. Cancer Ther. 2006; 5:1183-1189. [PubMed: 16731750]

Baehrecke EH. How death shapes life during development. Nat. Rev. Mol. Cell Biol. 2002; 3:779_ 787. [PubMed: 12360194]

Boya P, Gonzalez-Polo RA, Casares N, Perfettini JL, Dessen P, Larochette N, Metivier D, Meley D, Souquere S, Yoshimori T, Pierron G, Codogno P, et al. Inhibition of macroautophagy triggers apoptosis. Mol. Cell Biol. 2005; 25:1025-1040. [PubMed: 15657430]

Bursch W, Ellinger A, Kienzl H, Torok L, Pandey S, Sikorska M, Walker R, Hermann RS. Active cell death induced by the anti-estrogens tamoxifen and ICI 164384 in human mammary carcinoma cells (MCF-7) in culture: The role of autophagy. Carcinogenesis. 1996; 17:1595-1607. [PubMed: 8761415]

Bursch W, Hochegger K, Torok L, Marian B, Ellinger A, Hermann RS. Autophagic and apoptotic types of programmed cell death exhibit different fates of cytoskeletal filaments. J. Cell Sci. 2000; 113(Pt7):1189-1198. [PubMed: 10704370]

Canuto RA, Tessitore L, Muzio G, Autelli R, Baccino FM. Tissue protein turnover during liver carcinogenesis. Carcinogenesis. 1993; 14:2581-2587. [PubMed: 8269630]

Cao C, Shinohara ET, Niermann KJ, Donnelly EF, Chen X, Hallahan DE, Lu B. Murine double minute 2 as a therapeutic target for radiation sensitization of lung cancer. Mol. Cancer Ther. 2005; 4:11371145. [PubMed: 16093429]

Cao C, Subhawong T, Albert JM, Kim KW, Geng L, Sekhar KR, Gi YJ, Lu B. Inhibition of mammalian target of rapamycin or apoptotic pathway induces autophagy and radiosensitizes PTEN null prostate cancer cells. Cancer Res. 2006; 66:10040-10047. [PubMed: 17047067]

Chau YP, Lin SY, Chen JH, Tai MH. Endostatin induces autophagic cell death in EAhy926 human endothelial cells. Histol. Histopathol. 2003; 18:715-726. [PubMed: 12792883]

Clarke PG. Developmental cell death: Morphological diversity and multiple mechanisms. Anat. Embryol. (Berl.). 1990; 181:195-213. [PubMed: 2186664]

Daido S, Kanzawa T, Yamamoto A, Takeuchi H, Kondo Y, Kondo S. Pivotal role of the cell death factor BNIP3 in ceramide-induced autophagic cell death in malignant glioma cells. Cancer. Res. 2004; 64:4286-4293. [PubMed: 15205343]

Fesik SW. Promoting apoptosis as a strategy for cancer drug discovery. Nat. Rev. Cancer. 2005; 5:876-885. [PubMed: 16239906]

Folkman J. Angiogenesis: An organizing principle for drug discovery? Nat. Rev. Drug Discov. 2007; 6:273-286.

Franken NA, Rodermond HM, Stap J, Haveman J, van Bree C. Clonogenic assay of cells in vitro. Nat. Protoc. 2006; 1:2315-2319. [PubMed: 17406473] 
Gonzalez-Polo RA, Boya P, Pauleau AL, Jalil A, Larochette N, Souquere S, Eskelinen EL, Pierron G, Saftig P, Kroemer G. The apoptosis/autophagy paradox: Autophagic vacuolization before apoptotic death. J. Cell Sci. 2005; 118:3091-3102. [PubMed: 15985464]

Gozuacik D, Kimchi A. Autophagy as a cell death and tumor suppressor mechanism. Oncogene. 2004; 23:2891-2906. [PubMed: 15077152]

Ito H, Daido S, Kanzawa T, Kondo S, Kondo Y. Radiation-induced autophagy is associated with LC3 and its inhibition sensitizes malignant glioma cells. Int. J. Oncol. 2005; 26:1401-1410. [PubMed: 15809734]

Jaboin JJ, Shinohara ET, Moretti L, Yang ES, Kaminski JM, Lu B. The role of mTOR inhibition in augmenting radiation induced autophagy. Technol. Cancer Res. Treat. 2007; 6:443-447. [PubMed: 17877432]

Jemal A, Siegel R, Ward E, Hao Y, Xu J, Murray T, Thun MJ. Cancer statistics, 2008. CA Cancer J. Clin. 2008; 58:71-96. [PubMed: 18287387]

Kamada Y, Funakoshi T, Shintani T, Nagano K, Ohsumi M, Ohsumi Y. Tor-mediated induction of autophagy via an Apg1 protein kinase complex. J. Cell Biol. 2000; 150:1507-1513. [PubMed: 10995454]

Kanzawa T, Germano IM, Komata T, Ito H, Kondo Y, Kondo S. Role of autophagy in temozolomideinduced cytotoxicity for malignant glioma cells. Cell Death Differ. 2004; 11:448-457. [PubMed: 14713959]

Kanzawa T, Kondo Y, Ito H, Kondo S, Germano I. Induction of autophagic cell death in malignant glioma cells by arsenic trioxide. Cancer Res. 2003; 63:2103-2108. [PubMed: 12727826]

Kanzawa T, Zhang L, Xiao L, Germano IM, Kondo Y, Kondo S. Arsenic trioxide induces autophagic cell death in malignant glioma cells by upregulation of mitochondrial cell death protein BNIP3. Oncogene. 2005; 24:980-991. [PubMed: 15592527]

Kim KW, Hwang M, Moretti L, Jaboin JJ, Cha YI, Lu B. Autophagy upregulation by inhibitors of caspase- 3 and mTOR enhances radiotherapy in a mouse model of lung cancer. Autophagy. 2008a; 4:659-668. [PubMed: 18424912]

Kim KW, Moretti L, Lu B. M867, a novel selective inhibitor of caspase-3 enhances cell death and extends tumor growth delay in irradiated lung cancer models. PLoS ONE. 2008b; 3:e2275. [PubMed: 18509530]

Kim KW, Mutter RW, Cao C, Albert JM, Freeman M, Hallahan DE, Lu B. Autophagy for cancer therapy through inhibition of proapoptotic proteins and mTOR signaling. J. Biol. Chem. 2006; 3:142-144.

Kirkegaard K, Taylor MP, Jackson WT. Cellular autophagy: Surrender, avoidance and subversion by microorganisms. Nat. Rev. Microbiol. 2004; 2:301-314. [PubMed: 15031729]

Klionsky DJ, Abeliovich H, Agostinis P, Agrawal DK, Aliev G, Askew DS, Baba M, Baehrecke EH, Bahr BA, Ballabio BA. Guidelines for the use and interpretation of assays for monitoring autophagy in higher eukaryotes. Autophagy. 2008; 4:151-175. [PubMed: 18188003]

Lefranc F, Facchini V, Kiss R. Proautophagic drugs: a novel means to combat apoptosis-resistant cancers, with a special emphasis on glioblastomas. Oncologist. 2007; 12:1395-1403. [PubMed: 18165616]

Levine B, Klionsky DJ. Development by self-digestion: molecular mechanisms and biological functions of autophagy. Dev. Cell. 2004; 6:463-477. [PubMed: 15068787]

Liang XH, Jackson S, Seaman M, Brown K, Kempkes B, Hibshoosh H, Levine B. Induction of autophagy and inhibition of tumorigenesis by beclin 1. Nature. 1999; 402:672-676. [PubMed: 10604474]

Lum J, Deberardinis RJ, Thompson CB. Autophagy in metazoans: Cell survival in the land of plenty. Nat. Rev. Mol. Cell Biol. 2005; 6:439-448. [PubMed: 15928708]

Melet A, Song K, Bucur O, Jagani Z, Grassian AR, Khosravi-Far R. Apoptotic pathways in tumor progression and therapy. Adv. Exp. Med. Biol. 2008; 615:47-79. [PubMed: 18437891]

Mizushima N, Yamamoto A, Matsui M, Yoshimori T, Ohsumi Y. In vivo analysis of autophagy in response to nutrient starvation using transgenic mice expressing a fluorescent autophagosome marker. Mol. Biol. Cell. 2004; 15:1101-1111. [PubMed: 14699058] 
Mizushima N, Yoshimori T. How to interpret LC3 immunoblotting. Autophagy. 2007; 3:542-545. [PubMed: 17611390]

Moretti L, Attia A, Kim KW, Lu B. Crosstalk between Bak/Bax and mTOR signaling regulates radiation-induced autophagy. Autophagy. 2007; 3:142-144. [PubMed: 17204849]

Ogier-Denis E, Codogno P. Autophagy: A barrier or an adaptive response to cancer. Biochim. Biophys. Acta. 2003; 1603:113-128. [PubMed: 12618311]

Opipari AW Jr, Tan L, Boitano AE, Sorenson DR, Aurora A, Liu JR. Resveratrol-induced autophagocytosis in ovarian cancer cells. Cancer Res. 2004; 64:696-703. [PubMed: 14744787]

Paglin S, Hollister T, Delohery T, Hackett N, McMahill M, Sphicas E, Domingo D, Yahalom J. A novel response of cancer cells to radiation involves autophagy and formation of acidic vesicles. Cancer Res. 2001; 61:439-444. [PubMed: 11212227]

Reggiori F, Tucker KA, Stromhaug PE, Klionsky DJ. The Atg1-Atg13 complex regulates Atg9 and Atg23 retrieval transport from the pre-autophagosomal structure. Dev. Cell. 2004a; 6:79-90. [PubMed: 14723849]

Reggiori F, Wang C-W, Nair U, Shintani T, Abeliovich H, Klionsky DJ. Early stages of the secretory pathway, but not endosomes, are required for Cvt vesicle and autophagosome assembly in Saccharomyces cerevisiae. Mol. Biol. Cell. 2004b; 15:2189-2204. [PubMed: 15004240]

Rigas JR, Kelly K. Current treatment paradigms for locally advanced non-small cell lung cancer. J. Thorac. Oncol. 2007; 2 supp 12:S77-S85. [PubMed: 17589303]

Scarlatti F, Bauvy C, Ventruti A, Sala G, Cluzeaud F, Vandewalle A, Ghidoni R, Codogno P. Ceramide-mediated macroautophagy involves inhibition of protein kinase $\mathrm{B}$ and up-regulation of beclin 1. J. Biol. Chem. 2004; 279:18384-18391. [PubMed: 14970205]

Schwartz LM, Smith SW, Jones ME, Osborne BA. Do all programmed cell deaths occur via apoptosis? Proc. Natl. Acad. Sci. USA. 1993; 90:980-984. [PubMed: 8430112]

Schwarze PE, Seglen PO. Reduced autophagic activity, improved protein balance and enhanced in vitro survival of hepatocytes isolated from carcinogen-treated rats. Exp. Cell Res. 1985; 157:1528. [PubMed: 2857648]

Shao Y, Gao Z, Marks PA, Jiang X. Apoptotic and autophagic cell death induced by histone deacetylase inhibitors. Proc. Natl. Acad. Sci. USA. 2004; 101:18030-18035. [PubMed: 15596714]

Shimizu S, Kanaseki T, Mizushima N, Mizuta T, Arakawa-Kobayashi S, Thompson CB, Tsujimoto Y. Role of Bcl-2 family proteins in a non-apoptotic programmed cell death dependent on autophagy genes. Nat. Cell Biol. 2004; 6:1221-1228. [PubMed: 15558033]

Shintani T, Klionsky DJ. Autophagy in health and disease: A double-edged sword. Science. 2004; 306:990-995. [PubMed: 15528435]

Takeuchi H, Kondo Y, Fujiwara K, Kanzawa T, Aoki H, Mills GB, Kondo S. Synergistic augmentation of rapamycin-induced autophagy in malignant glioma cells by phosphatidylinositol 3-kinase/protein kinase B inhibitors. Cancer Res. 2005; 65:3336-3346. [PubMed: 15833867]

Wu YT, Tan HL, Huang Q, Kim YS, Pan N, Ong WY, Liu ZG, Ong CN, Shen HM. Autophagy plays a protective role during zVAD-induced necrotic cell death. Autophagy. 2008; 4:457-466. [PubMed: 18253089]

Yao KC, Komata T, Kondo Y, Kanzawa T, Kondo S, Germano IM. Molecular response of human glioblastoma multiforme cells to ionizing radiation: Cell cycle arrest, modulation of the expression of cyclin-dependent kinase inhibitors, and autophagy. J. Neurosurg. 2003; 98:378-384. [PubMed: 12593626]

Yu L, Alva Ajjai, Su Helen, Dutt Parmesh, Freundt Eric, Welsh Sarah, Baehrecke EricH, Lenardo MichaelJ. Regulation of an ATG7-beclin 1 program of autophagic cell death by caspase 8 . Science. 2004; 304:1500-1502. [PubMed: 15131264] 
Table 14.1

Characteristics of agents targeting autophagy in lung cancer

\begin{tabular}{|lll|}
\hline CLASS & AGENT & MECHANISM OF ACTION \\
\hline Lysosomal Protease Inhibitors & E64d & Lysosomal Inhibitor (proteases) \\
& Leupeptin & \\
& Pepstatin A & \\
& Vinca alkaloids & Microtubule Inhibitors \\
& Bafilomycin A 1 & Increases Lysosomal pH \\
Autophagy Sequestration Inhibitors & 3-methyladenine (3-MA) & Class I/III PI3K Inhibition \\
& LY294002 & \\
& Wortmannin & \\
& Cycloheximide & Not established \\
M687 (Kim et al., 2008b); Merck & Not established \\
Z-DEVD & Not established \\
Arsenic Trioxide & Inhibition of mTOR (Kanzawa et al., 2005) \\
Butyrate \& suberoylanilide hydroxamic & Histone Deacetylase Inhibitor (Shao et al., 2004) \\
acid & Ceramide & Increased Beclin 1 (Daido et al., 2004) \\
Rapamycin, RAD001 (Everolimus) & Inhibition of mTOR (Albert et al., 2006; Cao et al., 2006; \\
(Lefranc et al., 2007) & Kamada et al., 2000; Kim et al., 2006) \\
Resveratrol (Opipari et al., 2004) & Not established \\
Tamoxifen (Bursch et al., 1996, 2000) & Increased Beclin 1 expression (Scarlatti et al., 2004) \\
Temozolomide & DNA Alkylation (Kanzawa et al., 2004) \\
Endostatin (Chau et al., 2003) & Not established \\
\hline
\end{tabular}

